\title{
The Importance of Sustainability in the Fashion Sector: ADIDAS Case Study
}

\author{
Graziella Sicoli ${ }^{1}$, Giovanni Bronzetti ${ }^{1}$, Maria Baldini ${ }^{1}$ \\ ${ }^{1}$ Department of Business Science and Law, University of Calabria, Ponte P. Bucci 87036 Arcavacata Rende CS, \\ Italy
}

Correspondence: Graziella Sicoli, Department of Business Science and Law, University of Calabria, Ponte P. Bucci 87036 Arcavacata Rende CS, Italy.

Received: March 5, 2018

Accepted: April 17, $2019 \quad$ Online Published: May 16, 2019

doi:10.5539/ibr.v12n6p41

URL: https://doi.org/10.5539/ibr.v12n6p41

\begin{abstract}
In a society such as the present, characterized by an extremely consumerist lifestyle, the issue of social, economic and environmental sustainability must be taken into account and must become a conditioning element of day-to-day life choices by every business. To be a sustainable business means not only respecting the environment, but also respecting the health of workers and consumers, saving raw materials and economic resources, respecting human rights, rationalizing creative and productive processes, reducing waste, creating new and more transparent ties with communities. This implies a responsible behavior, with the aim to create value for all stakeholders. This is also affecting the fashion industry, where the problem of scarcity of resources and raw materials often leads to new entrepreneurial choices, which based on three important issues: saving, recycling, re-use. This study, using case study, examines the impact of sustainability policies implemented by some company operating in the fashion industry. Starting from these premises, the work intends to describe and analyze the application of the concept of sustainability in the field of fashion industry, focusing in particular on the Adidas case.
\end{abstract}

Keywords: sustainability, fashion sectors, case study

\section{Introduction}

Today, many companies, regardless of their sector, pay particular attention to the issue of corporate sustainability. The cause of this is to be found in the growing concern of companies and businesses over the excessive exploitation of natural resources and the consequent depletion of these resources. According to the Sustainability Revolution (Edwards, 2005), the survival and future development of both macro-systems (the planet earth, nations, etc.) and micro-systems (business and social organizations) presupposes the balance between three aspects Fundamental: environmental impacts, social implications and the achievement of adequate economic results (conservation and wealth creation). "Sustainability refers to the long-term maintenance of systems according to environmental, economic and social considerations" (Crane and Matten, 2007). The good sustainability practices adopted by companies and their adequate diffusion towards stakeholders can in the medium term become a source of competitive advantage and, therefore, contribute to the creation of value.The ability that businesses have to attract the best resources to ensure continuity and development, together with the attention of social stakeholders to which they must act while meeting their expectations, although these often appear to be irreconcilable between them, allows to build and/or strengthen mutual trust relations. Corporate Sustainability represents the condition for the survival and development of the enterprise system. However, it presupposes Corporate Social Responsibility as Corporate Sustainability and Corporate Social Responsibility are two concepts that are often confused and / or sometimes overlapping. Companies can adopt different strategies and tools to integrate good CSR practices with corporate sustainability. Such instruments are the formerly mentioned TBL tool (Daizy et al. 2013), the ten CSR principles by United Nations Global Compact (EC 2011), the guideline of the ISO-standard ISO 26000 for social responsibility (ISO 2014a) and Sustainability Reporting Framework by Global Reporting Initiative (GRI 2014a). In 2011, the European Commission updated its version on the definition of CSR. The reason behind the change was that initially, the definition was too broad in its meaning but the goal was also to be more in line with, and underline the core topics of, ISO 26000 (ISO 2012).

Corporate social responsibility must be pursued through responsible behavior that companies must adopt in 
terms of value creation not only for the shareholders but for all the stakeholders that come into contact with the company. The interest in this issue has led companies to set aside only the classic economic purpose, profit, to orient themselves towards the adoption of the "triple bottom line", or to a contemplative perspective (Elkington, 1997). Social nature (ensuring fairness and equal opportunities), environmental objectives (ensuring an ecological balance), economic goals (the ability to generate wealth). Through Corporate Social Responsibility, the company can balance the three sustainability objectives mentioned above (Wempe and Kaptein, 2002, Willard, 2005) and in this perspective, Corporate Social Responsibility can be seen as the basis for founding Corporate Sustainability. The growing importance attached to the theme of sustainability has led many companies to make tremendous efforts to implement sustainable practices related to the product / service offered (Yip et al., 2011). Companies are aware that doing so will not only help the environment and society, but can create a benefit for their reputation by positively contributing to the health of their brands. The theme of sustainability is becoming more and more relevant also in the field of fashion, where, by its very nature, the obsolescence of the product is further enhanced than the physical one, accelerating consumption dynamics and, therefore, use of natural resources. The basic idea is that of a fashion that creates value without destroying, generating and regenerating products respecting the environment. Starting from these premises, the paper intends to analyze how attention to sustainability in the fashion industry is a necessary condition for ensuring the company's competitive success and how social responsibility is intended to become an integral part of corporate value proposition as well as an additional element of Differentiation from many emerging countries.

The present work, after a brief introduction to CSR linkage and corporate value creation, clarifies the concepts of CSR and sustainability through an adequate review of the most significant national and international literature on the subject. Subsequently, it proposes an analysis of a casy study, describing the methodology used to select the sample examined and analyzing the main conclusions drawn by delineating some limitations that the study presents suggesting possible future research lines.

\section{Fashion and Corporate Social Responsibility}

Corporate social responsibility (CSR) becomes a source of competitive advantage when companies adopt a socially responsible behavior towards all stakeholders, even those that at first sight may seem not directly involved in the economic activities of the company. Companies must simultaneously commit to four types of responsibilities: economic, legal, ethical and philanthropic. The company that adopts socially responsible conduct, monitoring and meeting the economic, legal, ethical, environmental and social expectations of all stakeholders, achieves a competitive advantage by maximizing long-term profits (Kaptein and Wempe, 2002;). The aim of the venture is not to maximize profits and simply to comply with national and/or international regulations (Mc Williams and Siegel, 2001), but before undertaking every strategic decision must analyze the impact of its actions on all stakeholders, trying to balance their interests with their own and trying to provide an adequate remuneration for the contributions received.

The power is supposedly in the hands of the client, who has the final decision of whether to support sustainable business or not. Before going further into evaluating the customer perspective, it is necessary to distinguish the difference in terminology of the customer and the consumer. The customer is defined as the actor who purchases the product while the consumer is the person who uses the product. Thus, the customer can be, but does not have to be, the same as the consumer depending if it is the same person buying the product and using it or not. Client and customer are used as synonyms in this paper.

From a business-management point of view, the first studies on CSR came from the United States in the 1920s (Gay, 1927; Donham, 1929). These authors constantly referred to the responsibility of business men. Nonetheless, a univocal and universally accepted definition of CSR has not yet been constructed (Carroll, 1999; Thomas and Nowak, 2006) and only in recent years have a precise role and a specific evaluation been given to 'socially responsible' businesses (Garriga and Melé, 2004). CSR becomes a communication tool in order to reduce information asymmetry between companies and stakeholders (Schadewitz and Niskala, 2010). This social accountability must be carried out in conjunction with and complementary to the compulsory instruments (financial statements), in a unitary and systemic manner (Griffin and Mahon, 1997), while using its own instruments for performance measurement and external communication (Bendell, 2005). CSR can have both financial and strategic advantages for firms. By engaging in social activities and reporting on CSR, firms develop the trust and goodwill of stakeholders, which can provide them with competitive advantages (Aguilera et al. 2007; Money and Schepers 2007; Gill 2008; Kolk and Pinkse 2010). Research suggests that CSR reporting promotes firms' image and enhances their reputation, (Gray et al. 1995b; Vanhamme et al., 2012) as relationships with stakeholders are based on a positive exchange of benefits. Socially responsible firms tend to experience greater brand loyalty, customer satisfaction and employee commitment. CSR engagement also reduces the risk 
that firm performance is negatively affected by labour disputes, product safety scandals and consumer fraud (Waddock and Graves, 1997). Investors increasingly consider firms' social behaviour in their investment decisions (Simpson and Kohers, 2002; Aguilera et al. 2007;) Investors, therefore, increasingly require boards and managers to engage in CSR and report on this engagement (Scholtens, 2008; Kolk and Pinkse, 2010). Is a reciprocal expectation that firms 'balance the multiplicity of stakeholder interests' and 'are responsible to society as a whole'?

Moreover, CSR is clearly more important if we consider that companies using this type of approach might obtain better economic and financial results (Aupperle et al., 1985; McGuire et al., 1988; Waddock and Graves, 1997; Orlitzky et al., 2003).

More and more "intelligent" consumption forms are used, to consumers more aware of environmental and social risks, more aware of resource efficiency and willing to pay a higher price than competition from socially responsible businesses. This tendency is even more felt within the fashion industry, especially among young people, where social responsibility orientation is accompanied by attention to environmental sustainability and becomes an increasingly important element of doing business.

Joergens (Joergens, 2006) points out that manufacturing companies must pay particular attention to sustainable fashion aimed at young customers, as it will be the latter who will become the next generation particularly interested in ethical and solidarity-based purchases. Ethical forms of purchase are products selected on the basis of their characteristics of recyclability and respect for the external environment. (Shen et al. 2013). However, with the perspective of young consumers regarding ethical and sustainable fashion, Joy et al. (2012) found that young consumers do not associate sustainability with fashion today, even though they are open to environmental issues.

Social responsibility in the fashion sector is broader in the sense that the company must take on the expectations of the current and potential stakeholders, and must constantly monitor the environmental impact of their production throughout the production chain, Operating in order to reduce the consumption of natural resources, emissions of polluting substances into the atmosphere and waste water and the waste of processing residues. Although it can not be considered as one of the most critical areas of the environment, production in the fashion industry involves the adoption of socially responsible behavior in its business strategies, not only for ethical reasons or social recognition, but with the awareness that this It also translates into a profitable economic return or better competitive advantage. The interest of fashion companies in adopting socially responsible behavior introduces us into a new concept of eco-sustainable fashion, which is characterized primarily by the care and attention of the choice of raw materials to be used in the fashion chain. Companies, in fact, tend to prefer more and more natural and biological fibers, or from renewable resources or even from recycled materials; Secondly, many fashion companies are using vintage second-hand products and are implementing upcycling processes (converting waste materials into new, better quality materials with low environmental impact). Not to be neglected is the respect of workers' rights, as well as the importance of safety and health of workplaces and respect for human rights. Fashion-makers have perceived this and are implementing socially responsible behavior that goes beyond the basic practices of reducing emissions of polluting substances to safeguard health, well-being and workers' rights.

\section{The Sustainability in the Fashion Sector: A Literature Review}

To pursue sustainability practices, companies must be able to combine the three main dimensions of business development: the economic dimension, the social dimension and the environmental dimension. Sustained in corporate strategy, sustainability implies responsible behavior as a value creation for all stakeholders and not just for shareholders. The studies on sustainability and sustainable development have a double purpose: to limit the misuse of the term and seek effective sustainability indicators. In this new vision sustainability is not considered a cost, but a competitive advantage.

Most sustainability scholars agree that companies pursue sustainable development if they achieve their goals by eliminating and / or reducing the negative impacts of their activity on the environment and, if at the same time, meeting their needs of current stakeholders without compromising those of future stakeholders. The company pursuing Sustainable Behavior needs to incorporate CSR's economic, legal, ethical and philanthropic principles in its vision and strategy and business practices. These principles enable the three dimensions (People, Profit and Planet) of Corporate Sustainability to be funded, as these are naturally related to the various CSR-related responsibilities.

We talk about sustainable development when it creates situations of substantial balance between the three spheres social, economic and environmental, or if you prefer, whether it is valid the so-called rule of the balance 
of the three "E": ecology, equity, economy. A sustainable enterprise is therefore a reality organized with the aim of operating in a long-term perspective through the joint consideration of the economic, social and environmental dimension of its processes and performance (Goyal et al. 2013). The pursuit of objectives consistent with the concept of sustainable development and / or the implementation of a management model based on dialogue and the establishment of stable relations with its stakeholders Assures a firm life and creates value. The definitions of sustainability in the field of fashion industry refer to different concepts that are sometimes used with the same meaning, such as green, ethics, ecosystem, etc . This creates a lot of confusion (Shen et al., 2013). When we talk about sustainable fashion, we mean a fashion that incorporates fair trade solidarity, which respects proper working conditions without exploiting labor, which does not harm the environment and / or workers, which privileges the use of biodegradable substances, organic cotton (Joergens 2006), which uses recycled fabrics (Shen et al., 2013; Fletcher 2008). Sustainability in the fashion industry touches on different areas: from production to worker safety, to product quality and safety, to marketing, resource management Human resources, financial aspects. In Cannibals with Forks Elkington is describing sustainable development as the three bottom lines: environmental, economic and social (Elkington, 1997).

The three bottom lines are dependent on one another where society depends on the economy, which in turn depends on the global ecosystem, i.e. the environment. Over time, it has witnessed a true conceptual leap or a fundamental change in which the basic principles of economic behavior have been revised in the light of the new social dimensions. Switching to ecological and ethical production characterized by low resource consumption, reduced pollution, recycling of materials, working conditions and fairer pay, traceability, transparency and all other challenges that fall within the definition of sustainability is not a simple thing requires an entrepreneurial culture As well as many investments in this regard. Various fashion brands have long been implementing strategies to promote the use of materials and production processes in the respect of the environment and workers' rights, aspects considered nowadays as a source of value creation and competitive factor not to be underestimated. The ability to provide safety and well-being to your employees in work environments is essential to boost the efficiency of production processes and to support the new challenges of the fashion industry. In this area where quality prevails over quantity, the centrality of the product and its craftsmanship are of particular importance. There has been a real need for the consumer to contribute to respect for the environment in almost every sphere of everyday life. We are facing a consumer much more attentive than the past, an evolving consumer who enjoys a high value for money, more guarantees in the intrinsic product quality and traceability of the supply chain. The quantity of the product prefers the quality, the good product and well done adds a dimension between social and pleasure represented by the ability of the product to make it feel good, tied to the knowledge that a certain product has a special attention to the social made of linkage with the territory and fairness of relations with all stakeholders. European customers 50\% state that they are willing to pay more for a sustainable product, but the actual market share does not even reach $1 \%$. This inconsistency is known as the attitude-behaviour gap (Shen et al. 2013).

The perspective of the product life cycle involves the whole supply chain since it is appreciated that environmental impacts in a product's life can take place in all parts of the supply chain, and when evaluating the product life stages regarding sales and profits it includes the total supply chain as well. The recycling loop emphasises the desirable process of recycling in terms of sustainability at the end stage of the product life cycle. One can evaluate a product's life cycle in two ways depending on the purpose of the investigation. With the tool of Life-Cycle Assessment, the environmental impacts a product has through its life cycle can be investigated (Gmelin \& Seuring 2014) and with Kotler's Product Life Cycle the management can evaluate how a product is profitable through its different life stages (Kotler \& Armstrong 2009). Reusing is referred to as "the second life" where the product usually has the same function as before (Ligthart \& Ansems 2012).

The desire to live more sustainable has involved the fashion and fashion industry a lot, prompting many companies to rethink chain relationships, moving from opportunistic relationships to strategic partnerships. In such a context, the fashion industry, as has been the case in other manufacturing and service sectors, has rethought its competitive strategies and the underlying idea is a fashion that creates value without destroying, generating and regenerating products in Respect for the planet. In this context, fashion companies have started investing in sustainable development policies. This has increased attention to corporate social responsibility practices and the challenge has become to understand at what level an enterprise Is ethically and socially responsible, and how does it consider compliance with these issues as an inevitable condition for maintaining its economic performance. The concepts of fashion and sustainability have come closer and closer. The diversity among definitions of sustainability is also evident related to the fashion industry, making it complex to understand the criteria and the scope of sustainability in this industry. There are several concepts that are used for 
the same meaning, such as green, ethical and sustainable fashion, which creates confusion (Shen et al. 2013). When talking about sustainable fashion means refer to productions made with natural fibers using biological and biodegradable cotton, designed for a prolonged use in time and especially working in healthy place, which cause a low or no environmental impact and what makes use of eco-labelled or recycled materials. This definition will cover both the environmental and the social dimensions of sustainability, which makes the fashion sustainability definition more comprehensible and consistent (Shen et al. 2013).

Shen conducts a case study on a renowned fast-fashion brand, H\&M (Stockholm, Sweden), which has developed a sustainable fashion supply chain with the use of eco-materials and by following many sustainability guidelines. Based on the publicly available secondary data, the author reveals that H\&M's operations decisions may be associated with human well-being in different countries. To be specific, he finds that the sourcing team in H\&M tends to select suppliers in low-human-well-being countries and the supply chain team in H\&M may set a higher inventory level in the countries with higher human well-being.

\section{Fashion and Good Practices of Sustainability}

Fashion has a strong communicative and symbolic power and represents an element that identifies and influences individuals. Two are the main reasons driving fashion companies to adopt sound RSI practices and business sustainability: Firstly, because instances that come from the environment require behavior in that sense, secondarily because a healthy business under all circumstances raises an increase In terms of profitability and value creation. Fashion companies to communicate sustainability projects and respecting the appropriate quality standards of their productions have started on an annual basis to prepare dedicated sustainability reports and impact on the company's performance. A clear and transparent communication that enables current and potential stakeholders to understand the dynamics and strategies implemented to be sustainable to generate competitive advantages. In order to be sustainable it is necessary to involve all stakeholders, both primary and secondary. In addition, it must be clear what the objectives to be achieved are to be achieved, such as: energy and water saving, less waste of materials, reduced costs of non-sustainability, greater attention to local communities' needs, supply chain control Level and in every respect, close relationships with local communities based on transparency and mutual respect, constant attention to quality and compatibility of raw materials, security of their employees and their interest (Vigeo). Attention to sustainability in the fashion industry also concerns environmentalists, who constantly invite fashion makers to adopt non-polluting production policies, starting from tissues. It is good to remember some facts: cotton grows in about 80 countries (it is estimated that it occupies 33 million hectares of cultivable land) and provides about $32 \%$ of the volume of textile fibers used in the world; Has a heavy environmental impact due to water ( $73 \%$ of the fields is irrigated) and the chemicals used, it is enough to think that $6.2 \%$ of fertilizers and $14 \%$ of the pesticides sold in the world are destined for cotton. And then there are social problems and working conditions in the fields that often involve children. Cotton employs 250 million peasants, most of whom are in developing countries. Over the years, important initiatives have been developed to improve the fiber sustainability characteristics, as recalled by the report: Organic cotton born in the 80's (Fairtrade (2004): Particular attention to sustainability in the fashion industry comes from young designers who attach great importance to the choice of raw materials and eco-friendly materials, from traceable crops and environmental impact (for vegetable fibers) and that respect the Animal welfare (for animal fibers, for hides and fine materials), safeguard and protect biodiversity, avoiding the use of endangered species, preferring materials processed with natural substances or treatments that reduce consumption Of water and using alternatives to the use of hazardous chemicals.

\section{Case Study: Adidas Group and Its Efforts in Sustainability}

Within the "Best Global Green Brands" ranking, formulated by Interbrand, Adidas, Nike, Zara and H\&M are among the top 50 "green" brands for their strong commitment to environmental and sustainability policies and practices. Waste management, the development of innovative and environmentally friendly materials, involving employees in this process. H\&M is certainly one of Zara's major leaders in the affirmation of "fast-moving" clothing products from the longest life cycle. This is a highly appreciated fashion for its innovative charge and affordable but certainly more environmentally and socially criticized for the low "transparency" of the long supply chains; Responsible for low production costs. The criticisms that have gradually sagged on this business model have pushed H\&M to try to make their business more sustainable and acceptable. The latest Sustainability Report will set a measure of this commitment. The most significant issue is the publication of the supplier list, so that the supply chain is opened to environmental organizations checks and evaluations of confirmations of the commitments made regarding the materials used in the chemicals used, working conditions and to the protection of workers. Whoever works in the company knows how well the supply chain is considered to be a primary asset of the company. The availability of suppliers to open up to transparency was not free for H\&M and required 
incentive and training programs. Suppliers included in the list cover 95\% of production volumes and are located in both Europe and Asia. H\&M's Annual Report also presents other significant initiatives such as the one that allows its customers to deliver in their shops the disqualified items of any brand and under any condition in return for a discount voucher with the aim of "closing the circle" Of the materials used; Which would overcome all criticisms of the "consumerist" business model.

In the report we also find information that H\&M is the world's largest certified organic cotton buyer who, together with recycled cotton, covers $11 \%$ of its needs. H \& M is part of the Better Cotton Initiative. Lastly, in 2012, the distribution multinational has launched a water conservation initiative with WWF in collaboration with employee training programs, suppliers and customers.

This research focused on a single case study, AIDAS, in order to highlight its commitment from a sustainability point of view.

2000 for the first time, the Adidas Group was selected to join the Dow Jones Sustainability Indices (DJSI), since 2001 published a Sustainability Report on an annual basis; it is the only company in the sporting goods industry which does it.Adidas is a company that, since 1989, is committed to sustainability, recognizing the importance of it. The company has always been concerned about the surrounding environment. In order to carry out the search, the company website has been analyzed in detail, where there is a history of the company's sustainable engagement history since 1989. It is enough to think that it has prohibited the use of chlorofluorocarbons for all products and many Harmful chemicals have not been used to manufacture their products, because they are aware of their unfavorable environmental impact. Successive years have created the fundamentals for supply chain management.

In 1998 the Adidas Group developed its initial supplier code of conduct, called Workplace Standards. The Standards are based on international human rights and labour rights conventions. They are contractual obligations under the manufacturing agreements the Adidas Group signs with all its suppliers.

- The "Social \& Environmental Affairs" team was established to ensure suppliers' compliance with the company's Workplace Standards.

- In 1998, we also adopted a comprehensive and detailed Restricted Substances Policy for product materials, prohibiting the use of chemicals considered as harmful or toxic. This was the first policy in the industry that clearly indicated test and pre-treatment methods for restricted substances. Some of the initiatives that were thus generated were the phase-out of PVC materials from its main product categories, the first company in its industry to do so, as well as the introduction of new technologies to significantly reduce volatile organic compounds (VOCs) in footwear manufacturing by using innovative bonding technologies and water-based cement systems - both happening in the year 2000.

- Its factory in Germany was the first in the industry to receive EMAS environmental management system certification. This represents an important step in the efforts to reduce the environmental footprint of its facilities.

- 1999 marked the beginning of its formal Stakeholder Engagement approach, as the Adidas Group joined the Fair Labor Association (FLA) as a founding member. Since its inception, the FLA has focused on creating long-lasting solutions for sustainable supply chains. It is through the FLA that our supplier factories started being audited by external parties. Later, in 2005, the FLA accredited the Adidas Group's monitoring programme for the first time.

In 2000 for the first time, the Adidas Group was selected to join the Dow Jones Sustainability Indices (DJSI), which was positively welcomed by investors who integrate sustainability considerations into their portfolios. To date, the Adidas Group has since been listed in the DJSI every year. It was in a spirit of transparency and responsiveness towards its stakeholders that the company in 2001 published its first Sustainability Report. Still today, the Adidas Group is the only company in the sporting goods industry which publishes a Sustainability Report on an annual basis.

2002 represents a big year for the environment, as the company launched its Environmental, Health \& Safety Guidelines, as well as the Guide to Best Environmental Practice. These are comprehensive and detailed standards for suppliers on handling, storage and disposal of chemicals, waste water treatment and effluents. The guidelines were published and several brands in the apparel and sportswear industry have asked for permission to use our guidelines when dealing with their own suppliers.

In 2004 was born the Better Cotton Initiative (BCI), which addresses the negative social and environmental impacts of mainstream cotton farming, such as excessive pesticide and water use. Better Cotton is grown in a way 
that reduces the amount of chemicals used. Virtualisation became a strategic initiative for the company, which allows a reduction of the quantity of physical samples required to design and sell new products. With virtualisation, resources and money are saved by reducing material waste, transportation and distribution costs.

In 2006 the company became a member of the Fair Factories Clearinghouse, an industry-leading compliance data-sharing platform, which Reebok had co-founded, as well as the Leather Working Group, key to the establishment of an audit protocol for all our leather suppliers.

2007 represents the year of transparency, as the Adidas Group voluntarily disclosed its global supplier factory list. Few years later they became the Official Sponsor, Licensee and Outfitter of the 2010 FIFA World Cup South Afric, they were the first and only FIFA sponsor to do so. Since then, we have disclosed the list of factories manufacturing 2014 FIFA World Cup Brazil products, as well as the list for the London 2012 Olympic Games. Here as well, we were the first Olympic partner to disclose its supply chain for the Olympic Games.

In 2008 the company started dedicated environmental audits at its supplier sites - based on a rigorous environmental audit protocol that includes chemicals management (risk management, handling, use and storage of chemicals).

In 2010, among agreements and collaborations with international labour organization, the company launched its Environmental Strategy, which demonstrated the company's ongoing commitment to embedding environmental sustainability in all products, processes and services to significantly improve The Adidas Group's environmental footprint.

The collection for the London 2012 Olympic Games was the most sustainable Adidas collection ever produced. At the same time was launched a new technology which eliminates the need for water in the dyeing process, therefore also reducing the use of chemicals.

In the same year, Adidas hit the market introducing a new way of making products with no textile waste.

The year after, Adidas launch products made with environmentally preferred materials, with a low waste, innovating its way to create its products.

Other important thing is that the company is listed for the 14th consecutive time in the Dow Jones Sustainability Indexes and named leader in the "Textiles, Apparel \& Luxury Goods Industry" for the tenth time.

Since 2014 the company is ranks among the top 10 companies in the Global 100 Most Sustainable Corporations in the World, the most extensive data-driven corporate sustainability assessment in existence. To be more precise, the company ranks 8 th. The company presented its " $4 \mathrm{P}$ " sustainability strategy, rooted in its values - performance, passion, integrity and diversity and built on the achievements and learnings from previous years, while taking into account the societal landscape and future global trends.

Furthermore, the Group commits to being 99\% PFC free by no later than December 31, 2017.

In 2015 Adidas Group is ranked among the top three of most sustainable companies worldwide. It is recognized as best European company and as leader in its industry in the Global 100 Index by Corporate Knights. It signed a partnership with Parley for the Oceans, an environmental organization and collaboration network that raises awareness for the beauty and fragility of the oceans and implements comprehensive strategies to end their destruction. As founding member, Adidas supports Parley for the Oceans in its efforts in communication and education, research and development, direct action and eco innovation.

First footwear made with Ocean Plastic: In June, in the unique surroundings of the United Nations Headquarters Adidas showcases an innovative footwear concept born from its collaboration with Parley for the Oceans.

Fighting climate change, the company joins the UN Climate Neutral Now initiative to promote a wider understanding of the need and the opportunities for society to become climate neutral as well as to showcase that many organizations are already taking concrete action in this direction.

Some months after Adidas presents 'Sport Infinity', a research project led by Adidas and funded by the European Commission, bringing together a variety of industry and academic experts, with the aim of developing a material that can be endlessly recycled using a waste-free, adhesive-free process.

In 2015 Adidas Group is listed fifth among the 'Global 100 Most Sustainable Corporations in the World' and is recognised as the leader in its industry. It is the third consecutive year that the Group is included in the Top 10 of the Global 100 Index

Starting from the company's core belief that sport can have the power to change lives, the strategy "Sport needs a space" translates the Group's sustainable efforts into tangible goals and measurable objectives until 2020. Its 
strategy is built on the achievements and learnings from previous years, taking into account changes in the societal landscape, global trends and goes hand in hand with our overall business strategy. Its approach to sustainability reflects the feedback captured from stakeholders and sets clear targets to achieve.

There are many sustainability issues a multinational company might face. To identify the most relevant issues, Adidas looks at its business through different lenses. The following aspects guide the company in determining topics and issues of concern in its programmes and reporting:

- Peer-based and industry-wide norms: sustainability issues or standards that are developed by other companies or are addressed industry-wide and are used as benchmarks for its performance.

- Stakeholder concerns and societal trends: issues that are of high importance to its stakeholders including communities, non-governmental organisations (NGOs) and the general public, or reflect societal and consumer trends. Adidas regularly consults stakeholders on various topics to better understand their views, concerns and expectations.

- Opportunity for innovation: areas where the company can explore innovative solutions that benefit the environment, customers and other stakeholders to demonstrate sector leadership and create competitive advantage.

In order to be ensure that its Sustainability Strategy and programmes address the topics that are most material or salient to the business as well as the challenges ahead, the materiality assessment has been regularly updated based on our ongoing stakeholder engagement, driven by the Social \& Environmental Affairs department (SEA) - in close coordination with other corporate functions - with around 70 staff members in 14 countries. Due to their international background and local connectedness, they are well placed not only to know relevant stakeholders in key sourcing countries, but also to connect with them at a local, national and international level.

Stakeholder input is collected and centrally evaluated by SEA's senior management team to ensure that input from different groups is considered in a balanced way. Once significant changes to the previous year are identified, relevant topics are further followed up on, and classified according to their overall importance and relevance to our company. Based on this classification, key topics are integrated in the strategy and programmes and regularly report on the website and in annual publications.

The company recognises its responsibility to be accountable to all of its stakeholders, which involves regular and open reporting of our social and environmental performance.

Some stakeholders, in particular socially responsible investment (SRI) analysts, wish to see the annual reporting fully benchmarked against the reporting standards of the Global Reporting Initiative (GRI). In previous years they have relied on complete sustainability reports and some references in the annual financial report to meet the GRI requirements. Since 2012, information in the annual financial and sustainability report contributes to meeting these requirements. This allows the company to keep its sustainability report succinct and focused on performance and progress while qualitative information is reported on the corporate website.

This sustainability website section is where we provide information about the Adidas Group's sustainability goals, strategy, programmes and performance. The sustainability section:

- Focuses on what is most material for the company and for stakeholders;

- Supplies facts and figures about the key pillars of its programme: protecting workers in the supply chain, developing employees, contributing to local communities, and driving environmental progress;

- Discloses information about how the company put sustainability strategy into practice through guidelines, operating procedures and corporate policies;

- Provides news about developments or changes in our programmes;

- Publishes statements in different places that respond to stakeholder requests that have become of public interest;

- Archives data from previous years that allows readers to track our sustainability record and history;

- Includes links to other sections of our corporate website and to external websites where additional information can be found.

Sustainability report

The annual sustainability report focuses on the progress of the company in meeting its key targets for the year. The report also looks forward and presents the targets for the year ahead. 
VERIFICATION: the compamy recognises that some stakeholders want companies to ensure the content and data disclosed in their sustainability reports is independently verified. While they try to continuously improve the reporting systems for supplier monitoring data, they states that much of this data, in particular data on labour conditions, is not always verifiable in a standardised way. For this reason Adidas reporting does contain information that is subject to an annual review by the Fair Labor Association. They also refer to data verified when supplier factories or own facilities were certified to ISO, EMAS and OSHAS standards.

COVERAGE: The sustainability reporting covers all brands of the Adidas Group. It also refers at length to the activities of suppliers - both those with whom the Adidas Group has a direct contractual relationship (direct supply chain) and those whose contracts are with individual business units, agents or licensees (indirect supply chain

PERFORMANCE DATA: Reliable performance data is important. It allows to review the progress and plan next steps. By publishing that data the company invites its stakeholders to form their own view about company performance.

\section{Global Reporting Initiative}

Adidas recognizes that the GRI Guidelines are the international benchmark for sustainability reporting. Therefore, they use the GRI to inform the sustainability reporting and, in accordance with the G4 Core Guideline version, the company presents a content index highlighting where they have covered the GRI indicators in the reporting.

\section{Green company reports}

To carefully track the progress of its environmental initiatives and their impacts against targets, Adidas established a detailed environmental data recording and reporting system, which currently includes 48 sites and covers around $80 \%$ of the Adidas Group internal environmental footprint. Every year It publishes a special Green Company Performance Analysis that shows its achievements.

Being a sustainable business, Adidas is striking the balance between shareholder expectations and the needs and concerns of its employees, the workers in the supply chain and the environment. They believes that acting as a responsible business will contribute to lasting economic success. Adidas is continuously working towards becoming a more sustainable company, never stop learning and improving sustainability efforts.

\section{Conclusion}

The results of the paper show that ADIDAS, an important international brand, is among the top 50 "green" brand for their strong commitment to environmental and sustainability policies and practices. The development of innovative and environmentally friendly materials, the involvement of employees in this process, represent some of the sustainability efforts of ADIDAS and other fashion companies in the last years.

Summarizing, the research represents an important step in the sustainability items as focus attention on the importance of such variables which often condition and influence company's performance so it may be used from manager to implement firm performance. Further step of the research should be represented by the extension of fashion companies.

\section{References}

Aguilera, R. V., Rupp, D. E., Williams, C. A., \& Ganapathi, J. (2007). Putting the S Back in Corporate Social Responsibility: A Multi-level Theory of Social Change in Organizations. Academy of Management Review, 32(3), 836-863. Aguilera et al. 2006. https://doi.org/10.5465/amr.2007.25275678

Aupperle, K. E., Carroll, A. B., \& Hatfield, J. D. (1985). An empirical examination of the relationship between corporate social responsibility and profitability. Academy of Management Journal, 28(2), 446-463. https://doi.org/10.2307/256210

Bendell, J. (2005). In Whose Name? The Account Ability of Corporate Social Responsibility. Development in Practice, 15(3/4), 362-374. https://doi.org/10.1080/09614520500075813

Carrol, A. B. (1999). Corporate Social Responsibility. Evolution of a Definitional Construct, Business and Society, 38(3), 268-295. https://doi.org/10.1177/000765039903800303

Crane, A., \& Matten, D. (2007). Business Ethics, 2nd ed., Oxford University Press, New York.

Daizy, M. S., \& Niladri, D. (2013). Corporate Sustainability Reporting: A Review of Initiatives and Trends. Journal of Accounting Research \& Audit Practices, XII(2), 7

Davis, K. (1973). The Case for and against Business Assumption of Social Responsibilities. Academy of Management Journal, 16, 312-322. https://doi.org/10.5465/255331 
Donham, W. B. (1929). Business Ethics, A General Survey. Harvard Business Review, 7(4), 385-394.

Dyllick, T., \& Hockerts, K. (2002). Beyond the business case for corporate sustainability. Business Strategy and the Environment, 11(2), 130-141. https://doi.org/10.1002/bse.323

Edwards, A. R. (2005). The Sustainability Revolution, Potrait of a Paradigmshift, New Society Publichers, Gabriola Island, B.C., Canada.

Elkington, J. (1997). Cannibals with Forks. The Triple Bottom Line of 21st Century Business, Capstone Publishing, Oxford. https://doi.org/10.1002/tqem.3310080106

European Commission. (2001). Green Paper: Promoting a European Framework for Corporate Social Responsibility (Commission of the European Communities, Brussels).

Fletcher, K. (2008). Sustainable Fashion \& Textiles: Design Journeys. Oxford: Earthscan.

Gallante, C., Tartaglione, C., \& Guazzo G. (2012). Sostenibilità: moda Cosa significa, come si applica, dove sta andando l'idea di sostenibilità nel sistema moda, Soges.

Gao, S., \& Zhang, J. (1997). Stakeholder engagement, social auditing and corporate sustainability". Business Process Management Journal, 12(6), 722-740. https://doi.org/10.1108/14637150610710891

Garriga, E., \& Melé, D. (2004). Corporate Social Responsibility Theories: Mapping the Territory. Journal of Business Ethics, 53(1), 51-71. https://doi.org/10.1023/B:BUSI.0000039399.90587.34

Gay, F. F. (1927). The founding of the harvad Business School, in Harvad Business Review.

Gill, A. (2008). Corporate governance as social responsibility: a research agenda. Berkeley Journal of International Law, 26(2), 452-478.

Global ISO 2012, Sustainable events with ISO 20121.

Gmelin, H., \& Seuring, S. (2014). Achieving sustainable new product development by integrating product life-cycle management capabilities. International Journal of Production Economics, 154(C), 166-177. https://doi.org/10.1016/j.ijpe.2014.04.023

Goyal, P., Rahman, Z., \& Kazmi, A. A. (2013). Corporate sustainability performance and firm performance research: Literature review and future research agenda. Corporate Sustainability performance, 51(2), 361-379. https://doi.org/10.1108/00251741311301867

Gray, R., Kouhy, R., \& Lavers, S. (1995b). Methodological Themes Constructing a Research Database of Social and Environmental Reporting by UK Companies. Accounting, Auditing and Accountability Journal, 8(2), 78-101. https://doi.org/10.1108/09513579510086812

GRI (2014a). What is GRI? An overview of GRI, Global Reporting Initiative, https://www.globalreporting.org/information/about-gri/what-is-GRI/Pages/default.aspx Revived 2014-10-09

Griffin, J. J., \& Mahon, J. F. (1997). The corporate social performance and corporate financial performance debate. Business and Society, 36(1), ABI/INFORM. https://doi.org/10.1177/000765039703600102

ISO 2014a: ISO 26000 - Social responsibility, International Organization for Standardization, http://www.iso.org/iso/home/standards/iso26000.htm Revived 2014-10-09

Joergens, C. (2006). Ethical Fashion: Myth or Future Trend?" Journal of Fashion Marketing and Management 10(3), 360-371. https://doi.org/10.1108/13612020610679321

Joy, A., John, F., Sherry, J., Alladi, V., Jeff, W., \& Ricky, C. J. (2012). Fast Fashion, Sustainability, and the Ethical Appeal of Luxury Brands. Fashion Theory, 16(3), 273-296. https://doi.org/10.2752/175174112X13340749707123

Kaptein, M., \& Wempe, J. (2002). The Balanced Company: A Theory of Corporate Integrity, Oxford University Press, New York. https://doi.org/10.1093/acprof:oso/9780199255504.001.0001

Kolkm A., \& Pinkse, J. (2010). The integration of corporate governance in corporate social responsibility disclosures. Corporate Social Responsibility and Environmental Management, 17(1), 15-26. https://doi.org/10.1002/csr.196

Ligthart, T. N., \& Ansems, T. (2012). Modelling of Recycling in LCA. In Damanhuri E, editor. Post-Consumer Waste Recycl. Optim, pp. 185-211.

Marcel, V. M. (2003). Concepts and Definitions of CSR and Corporate Sustainability: Between Agency and Communion. Journal of Business Ethics, 44(2), 95-105. https://doi.org/10.1023/A:1023331212247 
McGuire, J. B., Sundgren, A., \& Schneeweiss, T. (1988). Corporate Social Responsibility and Firm Financial Performance. Academy of Management Journal, 31(4). https://doi.org/10.2307/256342

McWilliams, A., \& Siegel, D. (2001). Corporate Social Responsibility: A theory of the firm perspective. Academy of Management Review, 26(1). https://doi.org/10.5465/amr.2001.4011987

Money, K., \& Schepers, H. (2007). Are CSR and corporate governance converging?: A view from boardroom directors and company secretaries in FTSE100 companies in the UK. Journal of General Management, 33(2), 1-11. https://doi.org/10.1177/030630700703300201

Orlitzky, M., Schmidt, F. L., \& Rynes, S. (2003). Corporate Social and Financial Performance: A Meta-Analysis'. Organization Studies, 24, 403-442. https://doi.org/10.1177/0170840603024003910

Perrini, F., \& Tencati, A. (2006). The sustainability perspective: a new model, in Kakabadse A., Morsing M. (a cura di) Corporate social responsibility: reconciling aspiration with application, Houndmills-New York, Palgrave Macmillan, pp. 94-111. https://doi.org/10.1057/9780230599574_7

Schadewitz, H., \& Niskala M. (2010). Communication via Responsibility Reporting and Its Effect on Firm Value in Finland. Corporate Social Responsibility and Environmental Management, 17, 96-106. https://doi.org/10.1002/csr.234

Scholtens, B. (2008). Stakeholder relations and financial performance, 16(3), 213-232. https://doi.org/10.1002/sd.364

Shen, D., Richards, J., \& Liu, F. (2013). Consumers' Awareness of Sustainable Fashion. The Marketing Management Journal, 23(2), 134.

Simpson, W. G., \& Kohers T. (2002). The Link between Corporate Social and Financial Performance: Evidence from Banking Industry. Journal of Business Ethics, 35, 97-109. https://doi.org/10.1023/A:1013082525900

Thomas, G., \& Nowak, M. (2006). Corporate Social Responsibility: A definition, Graduate School of Business, Curtin University of Technology, Working Paper Series, December 2006, 62, pp. 1-20.

Vanhamme, J., Lindgreen, A., Reast, J., \& Popering, N. (2012). To do well by doing good: improving corporate image through cause-related marketing. Journal of Business Ethics, 109(3), 259-274. https://doi.org/10.1007/s10551-011-1134-0

Waddock, S. A., \& Graves, S. B. (1997). The corporate Social Performance-Financial Performance Link. Strategic Management Journal, 18(4), 303-319.

https://doi.org/10.1002/(SICI)1097-0266(199704)18:4<303::AID-SMJ869>3.0.CO;2-G

Wempe, J., \& Kaptein M. (2002). The Balanced Company. A Theory of Corporate Integrity Oxford University Press, Oxford/New York. https://doi.org/10.1093/acprof:oso/9780199255504.001.0001

Willard, B. (2005). The next sustainability wave: building boardroom buy-in, New society Publisher, Gabriola Island, Canada. https://doi.org/10.1145/1071916.1071917

Yip, E., Cahan, S., \& Van Staden, C. (2011). Corporate social responsibility and earnings management: the role of political costs. Australasian Accounting Business and Finance Journal, 5(3), 17-33.

\section{Copyrights}

Copyright for this article is retained by the author(s), with first publication rights granted to the journal.

This is an open-access article distributed under the terms and conditions of the Creative Commons Attribution license (http://creativecommons.org/licenses/by/4.0/). 